УДК $266.3: 261.6$

DOI 10.35423/2078-8142.2020.2.2.11

Б. С. Гулямов, аспірант кафедри богослов'я та релігієзнавства Національного педагогічного університету імені М. П. Драгоманова, м. Київ, Украӥна

e-mail: b.s.gulyamov1970@gmail.com

ORCID: https://orcid.org/0000-0001-8523-5420

\title{
ВЧЕННЯ СОЦАЛЬНОЇ ДОКТРИНИ КОНСТАНТИНОПОЛЬСЬКОГО ПАТРІАРХАТУ ПРО ШЛЯХИ ПОДОЛАННЯ БІДНОСТІ
}

У статті аналізуються основні риси сочіального вчення Вселенського патріархату щзодо проблеми бідності. Застосовано герменевтичний (аналіз окремих документів сочіальної доктрини Константинопольського патріархату) $і$ компаративний методи $з$ метою вивчення різних інтерпретацій сучасного сочіального вчення християнських церков щодо ставлення до проблеми бідності та шляхів ії подолання. Досліджується сочіальне вчення Вселенського патріархату про подолання бідності, яке залежить від уявлень сучасної теології про необхідність радикальної етичної солідарності 3 маргінальними ци експлуатованими верствами населення. 3'ясовано, шо сочіальне вчення Вселенського патріархату пропонує національним державам здійснювати політику соиіального захисту, виходячи з визнання абсолютної гідності кожної особистості та спираючись на досвід практики сочіальної дияконії і критичну аналітику сучасного глобалізованого капіталізму. Доведено, що сочіальне вчення Вселенського патріархату є аналогічним до ідей соиіальної доктрини папи Франциска, але при изьому залишається більш реалістичним та не ставить під сумнів сучасний капіталізм у цілому, а пропонує його реформування в напрямі розвитку культури спільнотності на основі застосування християнського морально-правового розуміння прав особистості. У сочіальному вченні Вселенського патріархату значна увага приділяється

(C) Гулямов Б. С., 2020 
моральним обов'язкам особистостей та спільнот щзодо солідарності з бідними, мігрантами, постраждалими від сочуіальних викликів сьогодення. Капіталістичний етос пропонується гуманізувати через прийняття моральної регулящії з боку вищих етичних ичінностей християнських спільнот, а не замінювати на посткапіталістичний етос християнського сочіалізму. Таким чином, сочіальна доктрина Вселенського патріархату стає виявом солідаризму, більш консервативного $і$ прокапіталістичного, ніж сочіальне вчення папи Франциска та політична теологія Джона Мілбанка.

Ключові слова: сочіальне вчення, Вселенський патріархат, проблема бідності, сочіальний захист, сучасний капіталізм.

Особливе значення для соціального вчення різних християнських церков має пропозиція можливих шляхів подолання бідності. Християнська соціальна доктрина як окрема богословська дисципліна виникла наприкінці XIX ст. у зв’язку з великою бідністю пролетаріату. Критика надмірних зловживань тогочасного капіталізму мала на меті завоювати прихильність представників бідних верств населення та повернути пролетаріат до церковних громад. Пропонуючи шляхи реформування капіталізму, соціальна доктрина намагалася відвернути пролетаріат і суспільство в цілому від ідей соціалізму та комунізму. Важливо, що наявність родини та участь у товарно-грошових відносинах заради їі забезпечення визнавалися природними для особистості. Звичайно, що католицизм $і$ православ'я ніколи не мали тих ідей безмежного збагачення, притаманним деяким течіям кальвінізму. Але в цілому сучасна наука довела, що у період появи капіталізму в Європі католицизм був значно більш прогресивно налаштований, ніж вважалося раніше. У творах багатьох сучасних дослідників позитивний вплив християнства і католицизму, зокрема, простежувався у періодичному створенні ідей та інституцій, які давали можливість відновлювати або оновлювати цивілізацію i культуру. Протестантське соціальне вчення від свого виникнення значною мірою було апологією капіталізму, і дискусії велися виключно про віднайдення балансу між ідеалом суспільства повної свободи та ідеалом соціальної держави. Православна церква традиційно проблемам захисту прав бідних приділяла мало уваги за межами риторики, яка спонукала б вірних 
до благодійності. Сьогодні в енцикліках папи Франциска та у соціальній доктрині Вселенського патріархату «За життя світу» відбувається радикальний поворот до систематичного захисту прав бідних, соціально-етичного та соціально-політичного осмислення проблеми бідності як такої, що вимагає докорінної реформації сучасного капіталізму і пошуків альтернативного соціального ладу, який можна було б назвати «солідаризмом». Цей лад, попри всю його альтернативність до капіталізму, не має впадати у спокуси соціалізму чи комунізму, які сьогодні осмислюються теологами як такі, що пов'язані з тоталітаризмом, але бути вираженням теорій комунітаризму, тобто вчення, в якому соціум у цілому має бути спільнотою спільнот. Загострення дискусій щодо ставлення до бідних у католицизмі та православ’ї вже не стимулюється ідеями «теології визволення» чи іншими альтернативними дискурсами, які поступово занепадають. Водночас, важко заперечувати появу дедалі більшої кількості ознак впливу на соціальне вчення католицизму і православ'я останніх років такої неоконсервативної течії, як радикальна ортодоксія, яка саме активно пропонує «солідаризм» $\mathrm{i}$ комунітаризм як важливі відповіді на основні виклики для релігійних та світських соціальних груп у часи постмодерну. Написана групою богословів, які перебувають під впливом радикальної ортодоксії, соціальна доктрина Вселенського патріархату «За життя світу» вимагає систематичного аналізу як приклад показової для початку XXI ст. систематичної критики капіталізму з позицій солідаризму.

Метою статті є аналіз основних рис соціального вчення Вселенського патріархату щодо проблеми бідності.

Застосовано такі методи дослідження: герменевтичний (аналіз окремих документів соціальної доктрини Константинопольського патріархату) і компаративний - 3 метою вивчення різних інтерпретацій сучасного соціального вчення християнських церков щодо ставлення до проблеми бідності та шляхів ії подолання.

Навколо нової соціальної концепції Константинопольського патріархату - документу «За життя світу», лише розпочинаються широкі богословські дискусії. Зовнішні оглядачі придивляються до рецепції цього документу в православній церкві, вирізняючи лише 
елементи деякого лібералізму, порівняно з аналогічними православними соціальними доктринами інших помісних церков $[3 ; 4 ; 8$; 11]. Водночас, документ «За життя світу» надає принципово нові загальні принципи для сучасного православного розуміння проблеми бідності, і тому озвучені в ньому ідеї потребують детального аналізу. Суголосні із цими ідеями концепції теології енциклік папи Франциска стали предметом обговорення переважно в Німеччині, оскільки саме там сильні традиції католицької легітимізації капіталізму та антикапіталістичний пафос останніх енциклік спричинив значну критику. Відповідно, дискусії у християнському соціальному вченні щодо бідності відбуваються у зв'язку з принциповою критикою сучасного глобального капіталізму, і внесок Вселенського патріархату в ці дискусії має бути предметом комплексного релігієзнавчого і соціально-філософського аналізу.

Соціальне вчення Вселенського патріархату на початку XXI ст., формуючи принципи ставлення до бідних, звертається до початків християнської традиції, до особливого досвіду християнських громад апостольської доби. Ці громади не мали потреби у розвинутій системі правової регуляції, оскільки самоочевидними були моральні норми, які безпосередньо здійснювалися через відносини любові [1, с. 6]. Прийняття іншого, притаманне громадам тієї доби, залишається дієвим для євхаристійного етосу церковних спільнот сьогодення. Ідеї філософії діалогу ХХ ст. та відповідної теології спілкування, що розвивається під впливом такої філософії, надали нового імпульсу актуалізації традицій ранньої церкви. Адже філософія діалогу та теологія спілкування відмовилися розглядати відносини повного прийняття іншого та любові, що панували у першому столітті як недосяжний для сьогодення ідеал, а наголошували на необхідності саме такої етики перед обличчям викликів для людяності, які постали у ХХ ст. у зв'язку з досвідом тоталітаризмів та світових війн. Усвідомлення необхідності стати на бік пригноблених у різних цивілізаційних контекстах сприяло оновленому сприйняттю соціального виміру сотеріології, особливо - старозавітних наративів визволення.

Також відмінною особливістю соціального вчення початку XXI ст. стало звернення до ідей святого Іоанна Золотоустого, який вважав матеріальні ресурси соціуму спільним надбанням, дарова- 
ним від Бога. Відповідно, приватна власність, на його думку, не $\epsilon$ абсолютною величиною, але чимось відносним. Переважно вона належить господарям, але вони мають обов'язок у випадку власного багатства ділитися 3 нужденними. Деякі християнські теологи сьогодення в ідеях Іоанна Золотоустого вбачають давній «християнський соціалізм», який сьогодні може бути актуалізований у нових умовах [13]. Значна кількість теологів звертається до ідей Августина, який був песимістом стосовно людської природи та можливостей встановлення правової справедливості. Августин наголошував на тому, що держава може забезпечити лише законність, далеку від ідеалів справедливості та інших морально-правових цінностей [14]. За таких умов значно зростає значення солідарності між громадянами, оскільки саме завдяки солідарним діям громад однодумців можливі благодійність, соціальна діяльність, реалізація цінностей у міжособистому спілкуванні та соціальному житті загалом. Сьогоднішня теологія особливо наголошує на актуальності соціального вчення Августина, абсолютизуючи значення спільнот, які характеризувалися наявністю міжособистих зв'язків, і саме у спільнотах вбачає образ Божий [12]. Звісно, вчення, за яким образом Божим є не окрема особистість, а спільнота, $є$ певним перебільшенням в інтерпретації, оскільки традиція дає мало підстав для такого бачення. Але такі ідеї неоавгустіанства суттєво впливають на соціальне вчення пап Бенедикта XVI і Франциска, які особливо наголошують на значенні солідарності та любові для конституювання спільнот [5; 15].

Ще більше значення для розвитку соціального вчення католицької і православної церков має різна оцінка великого багатства еліти й факту соціальної нерівності. Старий Завіт у багатстві вбачав велике благословення від Бога, Новий Завіт - джерело спокус, які ускладнюють досягнення Царства Божого. Це закладало основи середньовічної релігійної етики, згідно з якою багатство є легітимним лише у випадку широкої благодійності заможних. У добу модерну католицизм і православ'я продовжували мати стримане ставлення до накопичення багатства, тоді як протестантизм, здавалося б, стимулював появу «духу капіталізму». 
Різноманітні пропозиції шляхів подолання бідності у християнських соціальних доктринах початку XXI ст. зумовлені пошуком відповідей на виклики, пов'язані з великим соціальним розділенням між центрами і маргіналіями сучасного економічного світу, очевидною потребою у подоланні соціального розриву всередині багатьох націй, з новими викликами, які породжені глобальними соціально-економічними змінами, міграцією, очевидною (особливо після 2008 р.) кризою етосу чесного вільного підприємництва тощо.

Соціальне вчення Константинопольського патріархату підкреслює повноту солідарності Бога з маргінальними, соціально упослідженими, бідними верствами населення, що проявилося під час кенозису Боговтілення: «Коли Предвічний Син став людиною, відмовившись від Своєї божественної слави і змінивши «образ Божий» на «образ раба» (Флп. 2:6-7), Він у такий спосіб ототожнив Себе 3 найбільш маргінальними, політично безправними і соціально незахищеними людьми Свого часу. Народжений серед підвладного народу, який не мав жодних законних прав перед своїми імперськими колонізаторами, вихований у родині, що належала до нижчого ремісничого класу, Христос почав Своє служіння у внутрішніх районах Галілеї і присвятив його переважно найбільш знедоленим і безнадійним співвітчизникам» [1, с. 32]. Приклад Христа має велике значення для Його послідовників, які теж повинні бути солідарними з бідними та маргінальними членами суспільства. Соціальне вчення Вселенського патріархату підкреслює, що ця Христова солідарність з бідними не була чимось принципово новим для біблійного світогляду, оскільки у Старому Завіті, особливо - у книгах пророків, завжди наголошувалося на необхідності дієвого захисту бідних, сиріт, вдів тощо. Отже, «ця особлива прихильність до знедолених і зневірених аж ніяк не є лише випадковою складовою Його місії, зверненої до Ізраїлевих синів та дочок, але визначає саму їі суть» [1, с. 32].

Такі висновки стали можливими завдяки розвиткові сучасної біблеїстики, яка поглибила розуміння способів легітимізації різних соціально-політичних ідей у Біблії. А саме, з одного боку, у біблійному світогляді бачимо очевидну легітимізацію ідей соціального порядку, підтримку ієрархічно побудованого всесвіту. Такий ас- 
пект є притаманним всім давнім релігіям, і саме на нього тривалий час зверталася переважна увага. Сучасна біблеїстика багато розмірковує про паралелі з фігурою Бога як справжнього царя Ізраїлю та фараонів Сгипту, царів Близького Сходу. Але, водночас, саме у біблійному світогляді вбачаємо критику соціального порядку та пропозиції проектів побудови альтернативного соціуму [7]. Сучасна біблеїстика підкреслює унікальність такої критики для давнього світу. Влада Бога протиставляється владі царів земних, спочатку царів Сгипту, а потім навіть царів Ізраїлю. Порівняльний аналіз морально-правових системи минулого засвідчує значний гуманізм біблійного світогляду, намагання захистити права всіх, а особливо - соціально упосліджених осіб [9].

Актуалізація гуманістичного потенціалу біблійного світогляду в соціальній доктрині Вселенського патріархату відбувається не лише із застосуванням старозавітного наративу «звільнення». Декларація Константинопольського патріархату звертається до новозавітних ідей необхідності допомогти всім соціально упослідженим для їх повного звільнення та домагатися соціальної справедливості у боротьбі проти системних соціальних недоліків [1, с. 32]. Більше того, соціальне вчення підкреслює, що соціальна діяльність для християн та боротьба за соціальну справедливість не може бути чимось другорядним, факультативним: «Церква не може посправжньому йти за Христом або являти Його світові, якщо вона не поставить цю безумовну турботу про бідних і знедолених в осердя свого етичного, релігійного та духовного життя. Прагнення до соціальної справедливості та громадянської рівності - турбота про бідних, притулок для бездомних, захист слабких, гостинність до тих, хто залишив свої домівки, й допомога людям з інвалідністю це не просто ідеал, рекомендований Церквою заради заспокоєння совісті, але необхідний засіб спасіння, незамінний шлях до єднання з Богом у Христі» [1, с. 33]. Таким чином, соціальне вчення Православної Церкви поєднує сотеріологічний ідеал з конкретною діяльністю християн щодо їх історичного соціального оточення. Соціальне служіння суспільству, потребуючим верствам населення - це не щось додаткове до християнського життя, а його серцевина, сутність. У православній теології XX - початку XXI ст. були по- 
ширеними побоювання підмінити повноту Свангелія «соціальним євангелієм» за прикладом деяких протестантських богословів. Через ці побоювання склалася певна культура постійного наголосу на вищості православного етосу за цінності «соціального євангелізму». Обоження та церковну євхаристійну спільноту ідеалізували та показували як певну «земну трансцендентність», яка є самоцінною. Але соціальна доктрина Вселенського патріархату залишає ці рефлексії, звертаючись до євангельської етики та іï вимог. Таке відкриття соціального виміру євангельської етики стало можливим завдяки теології Іоанна Зізіуласа, який стверджував, що прийняття іншого є абсолютною етичною вимогою не лише Євангелія, а й православної аскетичної традиції, особливо - чернечої [10]. I це прийняття неможливе без соціальної діяльності як втілення етичної «радикальної солідарності» з бідними та нужденними. Ця радикальна солідарність $є$ самою суттю життя у Христі, тому іï не змогла знищити у православному етосі навіть тривала традиція одержавлення церкви [1, с. 33].

Соціальна доктрина Вселенського патріархату підкреслює, що християни скористалися державним визнанням церкви та іï державною підтримкою для розвитку соціальної діяконії. Декларація «За життя світу» наголошує, що «розуміння життя у Христі як радикальної солідарності було успадковане - на жаль, не цілковито, але значною мірою - епохою офіційно визнаної Церкви. Після навернення імператора Костянтина жодні зміни в імперській політиці не змогли втілити конкретних соціальних принципів Свангелія так само ясно, як масштабне розгортання церковної діяльності, спрямованої на допомогу бідним за великої матеріальної підтримки з боку держави» [1, с. 33].

Соціальна доктрина визнає, що це опертя на державу в діяконії церкви виникло з досвіду соціальної діяльності церковних громад у докостянтинівські часи. Ці громади становили альтернативну соціальну реальність спільнотного типу, що регулювалася виключно вимогами любові $[1$, с. 6]. Але вони не змогли забезпечити радикальних позитивних змін в імперії через принципову обмеженість власних можливостей, демонструючи здатність оновлення соціальності лише на прикладі життєдіяльності самої церкви [1, с. 33]: «У той час Церква не мала змоги по-новому формувати 
громадянське суспільство. У контексті негнучкого імперського правління вона також не мала змоги розробити якусь абстрактну політичну ідеологію, спроможну виправити або пом'якшити несправедливість епохи. Проте, християнам вдавалося у своєму оточенні дбати про бідних, особливо про вдів і сиріт (найбільш вразливі прошарки стародавнього світу), і створити в своєму середовищі суспільний устрій, заснований на любові, де ніхто не залишався покинутим напризволяще» [1, с. 33]. Очевидно, що сьогодні, коли церква і держави втрачають «симфонію» та пов'язані 3 нею форми філантропії, вже $є$ можливим вплив церкви на громадянське суспільство завдяки використанню мови прав людини як універсальної граматики для соціального діалогу [1, с. 12, 61]. Таким чином, християнське тлумачення прав людини дає можливість створити своєрідну неідеологічну ідеологію для соціального служіння в конкретних умовах сьогодення, які вимагають, серед іншого, співпраці християн із громадянським суспільством. Отже, сьогодення надає більше умов для розвитку соціальної активності церкви. I якщо вона менша та не така радикальна, як за часів ранньої церкви, то це цілком провина самих християн. Справді, часто у самих церковних громадах та за їх межами є певні категорії тих, хто потребує, але вони не отримують необхідної уваги. Однією 3 причин $€$ небажання заможних християн ділитися власними капіталами і можливостями.

Соціальна доктрина уникає обговорення відповідальності заможних християн, але зосереджується на покликанні всіх найзаможніших допомагати всім нужденним та на користі від законодавчого обмеження можливостей зростання соціальної нерівності [1, с. 35]. Підкреслюється, що соціальна нерівність досягла небувалих розмірів [1, с. 35]. Проте найбагатші як інвестори часто захищені від високих податків, тоді як звичайні громадяни несуть тягар соціальних витрат [1, с. 35], податковий тиск на середній клас дедалі більший $[1$, с. 35], робітники не отримують всієї можливої винагороди, оскільки корпорації зацікавлені у дешевій робочій силі [1, с. 35]. Тому, «на противагу такій практиці Православна Церква, безумовно, повинна наполягати на справедливості та співчутті як основоположних принципах податкової політики та керівних заса- 
дах справедливої оплати праці, а також на моральній відповідальності багатих робити якомога більший внесок у добробут суспільства загалом» [1, с. 35].

Очевидно, що питання податкової політики можуть регулюватися лише державною владою, а саме: «уряди мають запобігати несправедливому юридичному покриванню багатіїв або ухиленню від сплати податків» [1, с. 35]. Тому ідеї Августина і сучасного неоавгустіанства про те, що забезпечення у цілому суспільстві справедливості може бути здійснено через культуру солідарності малих спільнот є утопічними. Без державного справедливого розподілу ресурсів через правову, соціальну, податкову політики не може бути ніякої справедливості, оскільки кошти будуть вимиватися від усіх пересічних громадян та малих спільнот на користь корпорацій та багатіїв, що ми спостерігаємо у низці країн сьогодні. Наголос на провідній ролі держави та допоміжній ролі солідарності і любові $є$ принципом християнського реалізму, який де факто підтриманий у соціальному вченні Константинопольського патріархату.

Водночас, соціальна доктрина Вселенського патріархату використовує ідеї католицького соціального вчення останніх десятиліть про відносний характер приватної власності. Якщо у західному лібералізмі приватна власність - недоторкана, $є$ «другим тілом» для особистості (Дж. Лок), то для традиції Томи Аквінського, актуалізованої сьогодні у вченні останніх пап римських, права приватної власності можуть бути порушені, якщо цього вимагає загальне благо. Звичайно, що у православній соціальній доктрини це вчення про відносний характер приватної власності можна ввести через посилання на ідеї святих отців, що і робиться у документі «За життя світу»: «Твердження Отців Церкви про те, що ресурси творіння за вродженим правом належать усім людям, створеним на образ Божий, і що через це найзаможнішим із нас доручено неухильно ділитися своїм майном з бідними, можуть суперечити деяким укоріненим уявленням сучасного світу про приватну власність. Але вони є найважливішою основою християнського бачення цього світу як милостивого дару Божого і свідчать про відповідальність, яка, в очах Церкви, покладена на будь-яке справедливе суспільство» [1]. 
Популяризації погляду, що вся земля та всі земні багатства належать кінець-кінцем усьому людству найбільше сприяє папа Франциск [2]. Так само він підкреслює, що з цього, здавалося б, суто теоретичного положення, випливає обов'язок заможних ділитися з бідними [2]. Адже не лише землю, а й усі матеріальні багатства можна розглядати як такі, що даровані від Бога, зумовлені Його милістю. Відповідно, отримавши все у дар, особистість теж має бути здатною дарувати іншим власні надбання, власні сили, власний час. Порушення прав на приватну власність, згідно із сучасним лібералізмом, може бути виключенням із правил, зумовленим надзвичайними обставинами і потребами. Соціальна доктрина православ'я і католицизму сьогодні говорить про можливість більш широкого застосування підходу, згідно з яким принцип недоторканності приватної власності не є вищим за інші морально-правові принципи. Тим самим один 3 постулатів класичної соціальної доктрини християнства кінця XIX і XX століть розмивається, релятивізується.

Справді, соціальні виклики стають такими, що вимагають від людства дедалі більшої солідарності, дедалі більшого пріоритету духу моралі над буквою формального права. Але такий шлях $є$ дуже ризикованим при застосуванні його у соціальній практиці. Наприклад, у російській історії переважання прагнень до вищої правди і критичне ставлення до формального права призвели не до історичних досягнень, а до численних катастроф, оскільки правовий релятивізм призводив і до морального релятивізму. Систематичний аналіз наслідків заперечення необхідності правового підгрунтя для соціуму під час реалізації проектів будь-якої філантропічної надбудови було свого часу здійснено Б. Кістяківським, М. Бердяєвим, С. Франком. Не випадково, що соціальна доктрина Вселенського патріархату підкреслює, що необхідною є державна політика щодо надмірного багатства еліт та корпорацій, а соціальне вчення католицизму також закликає до правового вирішення цих проблем на міжнародному рівні.

Усі теорії християнського соціалізму або теології визволення про легітимність спонтанної моральної дії можуть сприяти появі нових різновидів тоталітарних практик. Адже правильні моральні 
мотиви самі по собі ще не гарантують правильності соціальних практик. Більше того, застосування державою або міжнародними органами правових норм щодо обмеження прав приватної власності заради певної соціальної користі - у цьому випадку заради подолання кричущої бідності, теж має бути таким, що не містить у собі порушення фундаментальних прав особистості. Простий перерозподіл соціальних благ від заможних до бідних не спричинить появу суспільства загального благополуччя. Бідним необхідно надати можливості ставати заможними завдяки власній праці, і це забезпечить збереження їх гідності та гідності усіх членів соціуму. Папа Іван Павло II вважав, що цей принцип слід застосовувати не лише до бідних верств населення в окремих націях, а й до бідних країн.

Важливо відзначити, що християнське соціальне вчення сьогодні визнає, що у західних суспільствах намітилася тенденція до зловживання ідеєю прав людини, до постулювання необхідності захисту прав певних пригноблених верств населення, навіть якщо цей захист призведе до певної дискримінації більшості чи значної частини населення. Для християнських теологів сьогодення $\epsilon$ зрозумілим, що таке зловживання матиме лише згубні наслідки, оскільки всякий правовий нігілізм веде соціум до радикальних криз і занепаду. Тому зрозуміло, що потрібно відмовитися від зловживань ідеєю прав людини, серед іншого - ідеєю прав бідних. Віднайдення балансу між вимогами справедливого внеску від еліти, корпорацій тощо та потребою зберегти права і гідність усіх членів соціуму має бути результатом діалогу у суспільстві, а не наслідком революційних дій. Усі революції «знизу» чи «зверху», які порушували правові основи сучасної демократії з ії граматикою прав людини, завершувалися негативно, навіть якщо це були революції в ім'я прав людини. Морально-правова свідомість має завжди виходити з пріоритету прав особистості та недоторканності ії життя від природного зачаття до природної смерті [1, с. 15]. Рухи, які не визнають цього постулату, не є гуманістичними, а $є$ нігілістичними, хоч би як адепти цих рухів самі себе не оцінювали. У цьому контексті особливо важливо підкреслити, що всі заяви сучасного християнського соціального вчення про можливість чи необхідність обмеження права приватної власності не $\epsilon$ проявом правового нігілізму, а покликані такому нігілізмові протистояти. 
Також на захист морально-правового порядку загалом та ідей абсолютної гідності особистості, зокрема, спрямована критика тенденцій сучасного глобалізованого капіталізму до перетворення праці на товар, приниження працівників редукцією їх особистості лише до корисних для ринку функцій праці та споживання [1, с. 36]. Адже працівників часто примушують до ненормованого робочого дня, і це призводить до «найманого рабства» навіть у розвинутих країнах $[1$, с. 36]. Ще більш відвертою $є$ експлуатація у країнах, що розвиваються, де штучно підтримується низька вартість робочої сили через позбавлення робітників прав та привілеїв [1, с. 36]. Соціальна доктрина Вселенського патріархату констатує: «Часто глобальні корпорації можуть скорочувати свої витрати i збільшувати прибутки, переносячи діяльність у ті регіони світу, де робоча сила коштує недорого саме тому, що працівники перебувають у відчайдушному стані, а місцеві органи влади більш зацікавлені в залученні іноземних інвестицій, ніж у проведенні гуманної трудової політики або навіть найелементарніших заходів із захисту праці. Це призводить до подвійного ефекту: зниження заробітної платні в розвинених країнах і посилення бідності в країнах, що розвиваються. До того ж, на периферії всіх ринків праці існують класи людей, які позбавлені правового захисту і, отже, піддаються експлуатації, не маючи можливості ефективно протидіяти їй у законному порядку: це, приміром, працівники без документів, яким доводиться погоджуватися на заробітну платню набагато нижчу від установленого законом мінімуму в обмін на найтяжчі види робіт, або переміщені та в буквальному сенсі поневолені жінки 3 країн, що розвиваються, яких примушують до торгівлі сексуальними послугами, разом з усіма зловживаннями, небезпеками і приниженнями, які тягне за собою таке життя» [1, с. 36].

Для католицької соціальної доктрини такі факти стають підставою для висновку про необхідність утвердження єдиної системи міжнародного права, формування світового уряду, який би мав повноваження принаймні вищої судової інстанції. Соціальне вчення Вселенського патріархату не пропонує таких механізмів, залишаючись на позиціях загальних закликів до національних держав провадити справедливе регулювання відносин між капіталом і працею, 
закликаючи міжнародні корпорації до того, щоб «гуманно інвестувати в депресивні регіони світу і створювати можливості там, де їх раніше не було» [1, с. 37].

Так, єдина світова влада скоріше слугуватиме інтересам міжнародного глобального капіталу, ніж створювати умови для правового захисту робітників та уникнення їх різноманітної антигуманної експлуатації. Соціальна доктрина відзначає, що на сьогодні як угоди про міжнародний вільний потік робочої сили, так і закони проти мігрантів призводять до дедалі більшої експлуатації працівників $[1$, с. 36]. Але при цьому все ж таки міжнародний законодавчий захист прав робітників є більш ефективним, ніж його відсутність й економічна автаркія національних ринків праці. Адже популістська політика протидії міграції, «негнучкі імміграційні закони і непроникні кордони» лише ведуть до утворення чорних ринків праці та сприяють злочинам проти мігрантів, нещадній їх експлуатації та розвитку «найманого рабства», а то і прямого фізичного примусу до праці та різноманітного продажу себе [1, с. 36]: «Безпринципні роботодавці вельми зацікавлені в тому, щоб різні національні ринки праці були максимально ізольовані один від одного, оскільки це має подвійний ефект: створення «тіньової» робочої сили $з$ незареєстрованих працівників, експлуатованих у межах національних кордонів, і збереження наявних депресивних ринків праці, експлуатованих за межами цих кордонів. Міжнародний вільний потік робочої сили, а разом з ним і здатність працівників самоорганізовуватися в глобальному масштабі й, отже, вимагати дотримання базових стандартів зайнятості на всіх ринках праці практично унеможливили б таку експлуатацію» [1, с. 36].

Цікаво, що соціальна доктрина католицизму, радикально солідаризуючись із мігрантами, пропонує конкретні заходи боротьби за їх права, наголошує на необхідності покращення життя мігрантів у країнах перебування, виступає за суттєві трансформації у країнах, з яких відбувається міграція. Православна соціальна доктрина, натомість, звертається до формальної та реальної влади - міжнародних організацій, держав, транснаціональних корпорацій - iз закликом дотримуватися загальної вимоги поваги до особистості. У документі «За життя світу» зазначається, що Церква просить про те, щоб «підприємства дотримувалися стандартів поведінки, які 
поважають властиву кожній людині гідність, і щоб вони вкладали інвестиції в економіку країн, що розвиваються, 3 метою поліпшення умов життя бідних верств населення, а не для того, щоб наживатися на їхніх злиднях» [1, с. 37]. Також підкреслюється, що «Православна Церква буде наполягати на високій гідності праці та на недоторканній священності кожної людини» [1, с. 37].

Сакральність кожної людини безумовна для соціального вчення Православної Церкви і тому вимога абсолютної поваги до особистої гідності, особливо у зв'язку з трудовими відносинами, $\epsilon$ загальним категоричним імперативом, який у кожних конкретних обставинах спонукає до різноманітної діяльності, але переважно надії покладаються все ж на державу як інститут, що має забезпечувати правовий захист особи. При цьому держава до такої діяльності має бути спонукувана громадянським суспільством, а це останнє, вочевидь, може надихатися християнськими ідеалами, що розкриваються церквою у іiі соціальному вченні [1, с. 38]. У результаті всіх цих дій «суспільство має забезпечити таку систему соціальної безпеки, яка дійсно захищала б бідних і знедолених від суцільних злиднів, деградації, бездомності, страждань і відчаю» [1, с. 38]. Найбільшими викликами для розвитку такої системи соціальної безпеки на національному та міжнародному рівні сьогодні стали непомірні військові витрати, «механізм незмірного боргу» низки держав перед міжнародними інституціями [1, с. 39], «відсутність доступу до належної медичної допомоги» [1, с. 40], «расова або класова дискримінація» [1, с. 41], яка виявляється у тому, що від таких криз, як екологічна, найбільше страждає населення слаборозвинутих країн [1, с. 41$]$.

Соціальна доктрина Вселенського патріархату моральною вимогою, актуальною для сьогодення, оголошує відмову держав від ескалації військових конфліктів: «Якщо держава не в змозі на постійній основі забезпечити навіть елементарний рівень загальної системи охорони здоров'я своїм бідним громадянам, якщо вона заплющує очі на тяжке становище найнужденніших, але при цьому щорічно витрачає непропорційно велику частину державних доходів на військову експансію, - ця держава займається тим, проти чого має повстати обізнана християнська совість» [1, с. 38]. Також 
Православна Церква у своїй соціальній доктрині звертається до прикладу біблійної практики ювілейного (періодичного) прощення боргів та наголошує, що багаті держави самі або через міжнародні інституції як власні інструменти мали б простити непомірні борги державам, що розвиваються [1, с. 39]. У соціальній доктрині Вселенського патріархату забезпечення бідних загалом та населення бідних країн, зокрема, оцінюється як моральний обов'язок заможних держав [1, с. 40]. Також упосліджене становище бідних країн, які стали постачальниками ресурсів для світової економіки та несуть основний тягар екологічних та інших втрат, оцінюється не лише як економічний факт, а як кричуще порушення соціальної справедливості [1, с. 41]. Наявність бідних верств населення і цілих держав не $є$ явищем закономірним, тому церква має обов'язок критикувати наявний глобальний соціальний порядок, закликати до його трансформації та пошуку можливості «нових економічних моделей», невідкладно дієво допомагаючи нужденним усім, чим тільки можливо, не очікуючи на загальне покращення стану справ [1, с. 41].

Доходимо висновків, що соціальне вчення Вселенського патріархату про подолання бідності в цілому залежить від уявлень сучасної теології про необхідність радикальної етичної солідарності 3 маргінальними й експлуатованими верствами населення. Спираючись на досвід практики соціальної дияконії та критичну аналітику сучасного глобалізованого капіталізму, це соціальне вчення пропонує національним державам здійснювати політику соціального захисту, виходячи з визнання абсолютної гідності кожної особистості. Таке соціальне вчення Вселенського патріархату є аналогічним до ідей соціальної доктрини папи Франциска, але при цьому залишається більш реалістичним та не ставить під сумнів сучасний капіталізм у цілому, а пропонує його реформування в напрямку розвитку культури спільнотності на основі застосування християнського морально-правового розуміння прав особистості. 


\section{ЛITЕРАТУРА}

1. За життя світу. На шляху до соиіального етосу Православної Церкви. The Greek Orthodox Archdiocese of America. URL: https://www.goarch.org/social-ethos?p_p_id=56_INSTANCE_km0Xa4sy 690V\&p_p_lifecycle=0\&p_p_state=normal\&p_p_mode=view\&p_p_col_id=c olumn-

1\&p_P_col_count=1\&_56_INSTANCE_km0Xa4sy69OV_languageId=uk_UA

2. Fratelli tutti. Енцикліка. Львів : Сзуїти в Україні, 2020. 125 c.

3. Asceticism, Ethics, and the Renewal of the Earth: Orthodox Christian Contributions to an Ecumenical Ecology By John Chryssavgis and Aaron Hollander. URL: https://www.atonementfriars.org/asceticism-ethics-and-therenewal-of-the-earth/.

4. Carrie Frederick Frost. The Orthodox Church and Its Social Ethos: The Aims and Accomplishments of For the Life of the World. Ecumenical Trends. Vol. 49 No 5. Graymoor Ecumenical \& Interreligious Institute. September/October 2020. P. 1-6.

5. Rowland T. Ratzinger's Faith. The theology of pope Benedict XVI. Oxford : Oxford University Press, 2008. 214 p.

6. Бенедикт XVI. Енцикліка Caritas in Veritate. Соиіальні документи Церкви (1891-2015). Львів : Свічадо, 2020. С. 408-476.

7. Брюггеман У. Пророческое воображение. Черкассы : Коллоквиум, 2012. $231 \mathrm{c}$.

8. Відеокурс Навколо документу «За життя світу»: дияк. М. Денисенко, О. Філоненко, архім. К. Говорун. Ethos. URL: http://www. ethos.org.ua/za-gittja-svitu

9. Головін С. Біблія і політика. Основи справедливого суспільства. Київ : Книгоноша, 2017. 136 с.

10. Иоанн (Зизиулас). Общение и инаковость. Новые очерки о личности и иеркви. Москва : ББИ, 2012. $407 \mathrm{c}$.

11. Йоан Хриссавгіс. Православна Церква й сочіальне вчення. Відкритий православний університет. URL: http://oou.org.ua/2020/03/27/shhodiznayemosya-za-zhyttya-svitu-sogodni-media-opublikuyut-dokument-prokerivni-prynczypy-pravoslavnoyi-czerkvy-u-suchasnomu-sviti

12. Милбанк Дж. «Постмодерный критический августинизм»: краткая сумма в 42 ответах на незаданные вопросы. Філософська думкаSententiae: Спецвипуск № 3 (2012) «Християнська теологія і сучасна філософія». Вінниця : ВДТУ, 2013. С. 108-120.

13. Сомін Н. В. Основні парадигми християнського ставлення до економіко-соціальної сфери. Християнин і світ. 2009. № 1. С. 22-27. 
14. Суини М. Лекиии по средневековой философии. Вып. 2: Средневековая политическая философия Запада. Москва : Греко-латинский кабинет Ю. А. Шичалина, 2006. 320 с.

15. Черноморец Ю. Учение о любви - фундамент сочиального учения Папь Бенедикта XVI. URL: http://orthodoxy.org.ua/node/4885

\section{REFERENCES}

Bartolini, M. G. (2017). Know Yourself. Neoplatonic sources in the work of G. S. Skovoroda. Kyiv: Akademperiodika, 160 p. [In Ukrainian].

Briskina-Müller, A. (2018). Reading as a forgotten category of ascetic theology of St. Isaac the Syrian, St. Gregory of Sinai and St. Paisius Velichkovsky. In: Bogoslovskij vestnik (Theological Bulletin), Vol. 31, 93-122. [In Ukrainian].

Kovalinsky, M. I. (1886). The Life of Gregory Skovoroda, written in an ancient style in 1794. In: Kievskaya starina (Kiev old), Vol. XVI.

Malakhov, V. A. (2008). Christological motives in G. Skovoroda's work, Pravo buty soboju. Kyiv: Spirit and Letter. [In Ukrainian].

Morozova, D. S. (2017). St. Paisius Velichkovsky at the crossroads of liturgical traditions of the18th century. In: Afonskoje nasledije (Mount Athos heritage), Vol. 5-6, 286-300.

Nichyk, V. M., Khyzhnyak, Z. (2000). Kyiv-Mohyla Academy and UkrainianGerman Cultural Relations. In: Naukovi zapysky KMA. Istorychni nauky (Scientific notes of the Kyiv-Mohyla Academy. Historical sciences), Vol. 18, 12-24. [In Ukrainian].

Okara, A. (1996). Paisius Velichkovsky and Gregory Skovoroda in the Context of 18th-Century Spirituality. In: Filosofiya. Istoriya kultury. Osvita (Reports and communications of the 3rd International Congress of Ukrainianists) (Philosophy. The history of culture. Education: Reports and Announcements of the Third International Congress of Ukrainianists). Kharkiv: Oko, p. 70-76.

Paisius, Velichkovsky. (2006). Autobiography. Life. Moskow, 203 p. [In Russian].

Skovoroda, G. (2011). Complete Works. Kharkiv: Maidan, 1398 p.

Skovoroda, G. (1973). Complete. Works in 2 Vols. Kyiv: Naukova dumka. 
Ushkalov, L. (2017). Hunting the Uncatchable Bird: The Life of Gregory Skovoroda. Kyiv: Spirit and letter. 368 p.

Chernomorets, Yu.P. Christian Platonism by Gregory Skovoroda. In: Philosophical Thought (Philosophical thought), Vol. 5, 88-97. [In Ukrainian].

Schmid, M. (1984). Epicuro et l'epicureismo cristiano. Brescia, 226 p.

\title{
Bohdan Gulyamov
}

Post-Graduate Student, Department of Theology and Religious Studies, National Pedagogical Dragomanov University; Kyiv, Ukraine; e-mail: b.s.gulyamov1970@gmail.com; ORCID: https://orcid.org/0000-0001-85235420

The teachings of the social doctrine of the Constantinople patriarchate on ways to overcome poverty

\begin{abstract}
Objective: the aim of the paper is the analysis of the main features of the social doctrine of the Ecumenical Patriarchate on the problem of poverty. Methods of research: the hermeneutic method - analysis of individual documents of the social doctrine of the Patriarchate of Constantinople; the comparative method - in order to study different interpretations of modern social teachings of Christian churches on the attitude to the problem of poverty and ways to overcome it. Conclusion: The social doctrine of the Ecumenical Patriarchate on overcoming poverty, which depends on the ideas of modern theology about the need for radical ethical solidarity with marginalized and exploited sections of the population are analyzed. The social doctrine of the Ecumenical Patriarchate proposes that nation states pursue a policy of social protection based on the recognition of the absolute dignity of each individual and based on the experience of social diakonia and critical analysis of modern globalized capitalism is studied. It is proved that the social doctrine of the Ecumenical Patriarchate is similar to the idea of the social doctrine of Pope Francis, but remains more realistic and does not call into question modern capitalism in general, but proposes its reform towards the development of community culture based on Christian moral understanding of individual rights. In the social teaching of the Ecumenical Patriarchate, much attention is paid to the moral responsibilities of individuals and communities in solidarity with the poor, migrants affect166
\end{abstract}

H.Skovoroda Institute of Philosophy of the NAS of Ukraine 
ed by the social challenges of today. It is proposed to humanize the capitalist ethos through the adoption of moral regulation by the higher ethical values of Christian communities, and not to replace it with the post-capitalist ethos of Christian socialism. Thus, the social doctrine of the Ecumenical Patriarchate becomes a manifestation of solidarity, more conservative and pro-capitalist than the social teaching of Pope Francis and the political theology of John Milbank.

Keywords: social doctrine, the Ecumenical Patriarchate, the problem of poverty, social protection, modern capitalism. 